\title{
Indomethacin-Enhanced Anticancer Effect of Arsenic Trioxide in A549 Cell Line: Involvement of Apoptosis and Phospho-ERK and p38 MAPK Pathways
}

\author{
Ali Mandegary, ${ }^{1}$ Maryam Torshabi, ${ }^{2,3}$ Mohammad Seyedabadi, ${ }^{2,4}$ Bagher Amirheidari, \\ Elham Sharif, ${ }^{5}$ and Mohammad Hossein Ghahremani ${ }^{2,6,7}$ \\ ${ }^{1}$ Neuroscience Research Center, Institute of Neuropharmacology, Kerman University of Medical Sciences, Kerman 7619813159, Iran \\ ${ }^{2}$ Department of Pharmacology and Toxicology, Faculty of Pharmacy, Tehran University of Medical Sciences, Tehran 1417614411, Iran \\ ${ }^{3}$ Department of Dental Biomaterial, Dental School, Shahid Beheshti University of Medical Sciences, Tehran 1473775543, Iran \\ ${ }^{4}$ Department of Molecular Imaging, The Persian Gulf Biomedical Sciences Research Institute, Bushehr University of Medical Sciences, \\ Bushehr 7514633341, Iran \\ ${ }^{5}$ Pharmaceutics Research Center, Institute of Neuropharmacology, Kerman University of Medical Sciences, Kerman 76175493, Iran \\ ${ }^{6}$ Department of Molecular Medicine, School of Advance Technologies in Medicine, Tehran University of Medical Sciences, \\ Tehran 1417755469, Iran \\ ${ }^{7}$ Basic and Clinical Toxicology Research Centre, Faculty of Pharmacy, Tehran University of Medical Sciences, Tehran 1417614411, Iran
}

Correspondence should be addressed to Mohammad Hossein Ghahremani; mhghahremani@tums.ac.ir

Received 27 April 2013; Accepted 21 September 2013

Academic Editor: Sherven Sharma

Copyright (C) 2013 Ali Mandegary et al. This is an open access article distributed under the Creative Commons Attribution License, which permits unrestricted use, distribution, and reproduction in any medium, provided the original work is properly cited.

\begin{abstract}
Background. Focusing on novel drug combinations that target different pathways especially apoptosis and MAPK could be a rationale for combination therapy in successful treatment of lung cancer. Concurrent use of cyclooxygenase (COX) inhibitors with arsenic trioxide (ATO) might be a possible treatment option. Methods. Cytotoxicity of ATO, dexamethasone (Dex), celecoxib (Cel), and Indomethacin (Indo) individually or in combination was determined at 24, 48, and 72 hrs in A549 lung cancer cells. The COX-2 gene and protein expression, MAPK pathway proteins, and caspase-3 activity were studied for the most cytotoxic combinations. Results. The $\mathrm{IC}_{50} \mathrm{~s}$ of ATO and Indo were $68.7 \mu \mathrm{mol} / \mathrm{L}$ and $396.5 \mu \mathrm{mol} / \mathrm{L}$, respectively. Treatment of cells with combinations of clinically relevant concentrations of ATO and Indo resulted in greater growth inhibition and apoptosis induction than did either agent alone. Caspase-3 activity was considerably high in the presence of ATO and Indo but showed no difference in single or combination use. Phosphorylation of p38 and ERK1/2 was remarkable in the concurrent presence of both drugs. Conclusions. Combination therapy with ATO and Indo exerted a very potent in vitro cytotoxic effect against A549 lung cancer cells. Activation of ERK and p38 pathways might be the mechanism of higher cytotoxic effect of ATO-Indo combination.
\end{abstract}

\section{Introduction}

Health care practitioners face a huge burden caused by lung cancer. Lung cancer is also responsible for a considerable share of cancer-induced mortalities, which is estimated to exceed 800,000 annual deaths worldwide [1]. One clinical obstacle to successful cure of lung cancer is the resistance to chemotherapeutic agents. Besides, the side effects of drug regimens routinely employed in cancer treatment are associated with the treatment failure. One way to overcome these complications is to utilize multiple drugs enlisting various mechanisms to attack the disease [2]. Combination chemotherapy aimed at increasing cytotoxic efficacy has experienced a huge evolution over recent decades [2]. A shared mechanism of resistance towards a chemotherapeutic drug is the failure of the tumor cells to go into apoptosis. Hence, interest has been raised to exploit this path to circumvent drug resistance.

This might justify the routine use of combination chemotherapy in the treatment programs of lung cancers. However, treatment efficacy has not always been promising even when recently formulated combinations were used. This 
has opened a window to explore the utilization of other agents which might not even be a part of current general cancer therapy strategies. Arsenic trioxide (ATO) is presently only used for the treatment of acute promyelocytic leukemia (APL) under the approval of FDA [3]. Application of ATO in combination with other agents in different cancers including lung could potentially provide an effective therapeutic tool. In addition, there are alternative mechanisms which can promote the apoptotic death of cancerous cells. A large body of evidence has shown a significant increase in expression of cyclooxygenase-2 (COX-2) in variety of cancers [4-6]. Thus, many COX inhibitors have been shown to prevent or delay development of certain tumors including lung cancer. It has been reported that nonsteroidal anti-inflammatory drugs (NSAIDs) including celecoxib and indomethacin can induce apoptosis in various types of lung cancer cells [710]. Furthermore, dexamethasone, a potent synthetic glucocorticoid which inhibits cyclooxygenase none selectively $[11,12]$, is being used in various cancer treatment protocols to prevent cancer progression and/or avoid side effects of chemotherapeutic agents [13-15]. However, lines of evidence of NSAIDs' antilung cancer effects due to the COX-2 inhibition are conflicting $[9,10,16,17]$.

It is notable that ATO can induce apoptosis in a variety of hematologic and solid tumor cancer cells, for which several mechanisms have been accounted [18-20]. Recently we have shown that ATO induces apoptosis and caspase- 3 activation in the bone marrow promyelocytes of newly diagnosed APL patients through upregulation of p38 MAPK and Bax [21]. Despite the good therapeutic effects in APL even at low concentrations, the results obtained in non-APL patients have not been encouraging. For this reason enormous efforts have been made to provide effective combinations of ATO with other agents [22-24].

Therefore, this study aimed at investigating the effects of upstream, selective and nonselective COX inhibition, that is, dexamethasone, celecoxib, and indomethacin, respectively, on ATO-induced cell apoptosis in human lung cancer cell line.

\section{Materials and Methods}

2.1. Reagents. Arsenic trioxide $\left(\mathrm{As}_{2} \mathrm{O}_{3} ; \mathrm{ATO}\right)$ was obtained from Sina-Darou (Iran) in the stock concentration of $5 \mathrm{mM}$ and then diluted with PBS to a working concentration of $50 \mu \mathrm{M}$. Dithiothreitol (DTT), Tripure, Western blot detection kit, XTT assay kit, and polyvinylidene difluoride (PVDF) membrane were from Roche Applied Science (Germany). Anti-extracellular receptor kinase 1/2 (ERK1/2), phospho-ERK1/2, p38, phospho-p38, jun N-terminal kinase (JNK), Akt, Bax, COX-2, and $\beta$-actin antibodies were purchased from Cell Signaling Technology (USA). Bromophenol Blue, Coomassie blue R-250, and caspase-3 colorimetric assay kit were purchased from Sigma Chemical Company (UK). RPMI-1640, Fetal Bovine Serum (FBS), penicillinstreptomycin, and trypsin-EDTA were purchased from BioSera (Korea). BioMax film was obtained from Kodak (UK). M-MuLV, primers, dNTPs, and Taq DNA polymerase were from Fermentas Life Science (Lithuania). Indomethacin (Indo) and Celecoxib (Cel) were kindly provided by a collaborative lab (as 98.8\% purity) [25] and dissolved in minimal amounts of dimethyl sulfoxide (DMSO) so that the final DMSO in test wells did not exceed $1 \%$. All other chemicals were from Merck (Germany).

2.2. Cell Culture. The A549 cell line (human lung adenocarcinoma epithelial cells) was cultured at $1 \times 10^{5}-1 \times 10^{6}$ cells per mL in RPMI 1640 medium supplemented with $10 \%$ FBS, $100 \mathrm{U} / \mathrm{mL}$ penicillin, and $100 \mathrm{mg} / \mathrm{mL}$ streptomycin in a humidified atmosphere with $5 \% \mathrm{CO}_{2}$. All the treatments were carried out on cells in logarithmic phase of growth.

2.3. XTT Assay for Cellular Proliferation. Cells (7,000 cells per well) were seeded into 96-well flat-bottomed microplates and let adhere onto the surface. ATO $(2-150 \mu \mathrm{M})$, Indo $(2-$ $800 \mu \mathrm{M})$, Cel $(5-150 \mu \mathrm{M})$, and Dex $(10-200 \mu \mathrm{M})$ and their combinations (at concentrations indicated in the graphs) were added to the wells. To measure viability, $50 \mu \mathrm{L}$ fresh XTT labeling mixture $(49 \mu \mathrm{L}$ XTT labeling reagent and $1 \mu \mathrm{L}$ electron coupling reagent) was added after 24,48 , and $72 \mathrm{hrs}$ and incubated for $4 \mathrm{hrs}$ at $37^{\circ} \mathrm{C}$ in $5 \% \mathrm{CO}_{2}$ atmosphere. Cell viability was assayed in quadruplicate, and the whole experiments were repeated three times. Absorbance at $450 \mathrm{~nm}\left(\mathrm{~A}_{450 \mathrm{~nm}}\right)$ of the formazan was measured using a microplate reader, and the results were expressed as a ratio of the treated cells over the untreated vehicle cells. Solvent control trials were performed appropriately and exhibited no cytotoxic effects.

2.4. Protein Isolation and Western Blotting. Cell extracts were prepared by lysing the ice-cold PBS washed cells in the designated times by using $100 \mu \mathrm{L}$ lysis buffer $(50 \mathrm{mM}$ HEPES, pH 7.4, $5 \mathrm{mM}$ CHAPS, $5 \mathrm{mM}$ DTT) at $4^{\circ} \mathrm{C}$ for $15 \mathrm{~min}$. Extracts were then centrifuged at $14,000 \mathrm{~g}$ in a microfuge at $4^{\circ} \mathrm{C}$, and supernatants were transferred to fresh tubes. Protein concentration was determined by Bradford assay method. Thirty $\mu \mathrm{g}$ of proteins was added to an equal volume of $2 \mathrm{X}$ SDS-sample buffer and run on a $10 \%$ sodium dodecyl sulfatepolyacrylamide gel (SDS-PAGE). Proteins were transferred to PVDF membranes (Roche), stained with $0.1 \%$ Ponceau S to ensure equal protein loading, and blocked with $1 \%$ casein in TBS (50 mM Tris, $150 \mathrm{mM} \mathrm{NaCl}$ ) for 1 hour at room temperature. The membranes were then hybridized overnight at $4^{\circ} \mathrm{C}$ with polyclonal anti-Bax $(1: 2000)$, anti-Cox-2, anti-p38 (1:1000), anti-ERK1/2 (1:1000), anti-JNK (1/1000), anti-Akt (1/1000), anti-phospho-ERK, anti-phospho-p38, and anti- $\beta$ actin $(1: 1000)$ antibodies (Cell Signaling, USA). Following 2 washes with TBS-T (TBS containing $0.1 \%$ Tween-20) and one wash with TBS for 12 minutes each, blots were incubated with a goat anti-mouse/rabbit-antibody-HRP conjugate (Roche) for $1 \mathrm{hr}$ at room temperature. After washing the blots as previously, bands were visualized by adding luminal substrate to the blots and exposure to the BioMax film (Kodak).

2.5. Isolation of Total Cellular RNA, cDNA Synthesis, and $R T-P C R$. RNA was isolated from log phase cultures of the cell lines. Cells were harvested by centrifugation at $110 \mathrm{~g}$ 
for 5 min and washed with PBS and total cellular RNA was extracted using TRIPURE reagent (Roche, Germany) following the manufacturer's instruction. RNA concentration and its purity were estimated by measuring the absorbance at 260 and $280 \mathrm{~nm}$. Isolated RNAs were stored at $-80^{\circ} \mathrm{C}$ and subsequently used for semiquantitative RT-PCR. Single stranded cDNA was synthesized using M-MuLV Reverse Transcriptase (Fermentas, Lithuania) and random hexamer primers according to the manufacturer's protocol.

For RT-PCR $1 \mu \mathrm{g}$ of cDNA was used as the target in a total volume of $25 \mu \mathrm{L}$. Reactions were performed according to standard protocols using the following primers and conditions: for Cox-2 (GenBank: AJ634912.1) forward 5'-AGC TGG GAA GCC TTC TCT AAC- $3^{\prime}$ and reverse $5^{\prime}$-AGA TCA TCT CTG CCT GAG TAT CTT- $3^{\prime}$ and for $\beta$-actin (as internal control; GenBank: X00351) forward 5'-GAT GAT GAT ATC GCC GCG CT- $3^{\prime}$ and reverse $5^{\prime}$-CTT CTC GCG GTT GGC CTT GG-3' ${ }^{\prime}$ primers were used. PCR condition for COX-2 and $\beta$-actin was 35 cycles of denaturation at $94^{\circ} \mathrm{C}$ for $30 \mathrm{sec}$, annealing at $55^{\circ} \mathrm{C}$ for $30 \mathrm{sec}$, and extension at $72^{\circ} \mathrm{C}$ for $30 \mathrm{sec}$. PCR products were electrophoresed on a $1.5 \%$ agarose gel containing $500 \mu \mathrm{g} / \mathrm{L}$ ethidium bromide and visualized with UV light. The amplified bands for COX-2 and $\beta$-actin were 302 and $351 \mathrm{bp}$, respectively. All experiments were performed three times.

2.6. Caspase-3 Activity Assay. Activity of caspase-3 was assayed according to the manufacture guideline (Sigma). Briefly, $30 \mu \mathrm{g}$ of lysate, $90 \mu \mathrm{L}$ of assay buffer (20 mM HEPES, $\mathrm{pH} 7.4,0.1 \%$ CHAPS, $5 \mathrm{mM}$ DTT, $2 \mathrm{mM}$ EDTA) and $10 \mu \mathrm{L}$ of caspase-3 substrate Ac-DEVD-pNA $(2 \mathrm{mM})$ were added to each well of a flat-bottom 96 well. As positive control, the caspase-3 pure protein was used. For measuring the nonspecific hydrolysis of the substrate, an inhibitor-treated cell lysate control was included. Microplate was incubated at $\mathrm{CO}_{2}$ incubator and O.D. $405 \mathrm{~nm}$ was measured in $4 \mathrm{hrs}$ (in this time there was the biggest difference).

2.7. Statistical Analysis. Statistical analysis was done using SPSS software (version 11.0). Data were expressed as Mean \pm $\mathrm{SD}$. One-way analysis of variance (ANOVA), followed by the Tukey HSD, was used to assess significant differences between treatment groups. Differences were considered as significant when $P<0.05$. The $\mathrm{IC}_{50}$ was calculated using Probit command in the SPSS.

\section{Results}

3.1. Arsenic Trioxide Inhibits the Growth of A549 Cells Dose- and Time-Dependently. ATO-induced inhibition of cell growth in A549 is illustrated in Figure 1. To explain further, a decrease in viability along with dose increments and time extensions is evident. Since the 24 and $48 \mathrm{hrs}$ treatments had no significant cytotoxicity, assays were focused on the $72 \mathrm{hrs}$ treatment. The dose-response curve of ATO, Cel, Indo, and Dex on cell proliferation at $72 \mathrm{hrs}$ is shown in Figure 2. All the drugs, except Dex, induced cytotoxicity in a dose-dependent manner at $72 \mathrm{hrs}$. The calculated $\mathrm{IC}_{50} \mathrm{~s}$

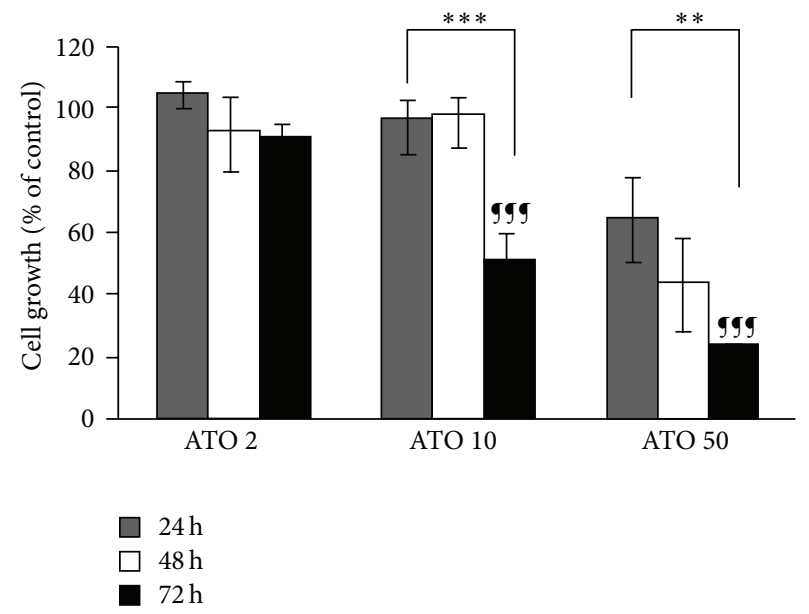

FIGURE 1: Effect of different incubation time on the cytotoxicity of ATO on the A549 cell line (Mean \pm SE, $n=4 ;{ }^{* *} P<0.01$ and ${ }^{* * *} P<$ 0.001; ${ }^{\text {g99 } P}<0.001$ compared to ATO $2 \mu \mathrm{M}$ ).

(concentration causing $50 \%$ growth inhibition) of agents were $68.7,98.2$, and $396.5 \mu \mathrm{M}$ for ATO, Cel, and Indo, respectively. Dex did not inhibit cell growth up to $200 \mu \mathrm{M}$ (Figure 2).

3.2. Arsenic Trioxide in Combination with Indo, and Not Dex or Cel, Produces More Potent Growth Inhibition Than with Either Agent Alone. Because ATO, Cel, and Indo had fairly high $\mathrm{IC}_{50}$ as single agent, we hypothesized that combination of these drugs would be more efficient to suppress the growth of the cells. We also tested the effect of Dex on the cytotoxic effect of ATO. Thus, cells were treated with combinations of Indo $(1,10$, and $50 \mu \mathrm{M})$, Cel $(5,25,50$, and $75 \mu \mathrm{M})$, Dex $(1,5$, and $50 \mu \mathrm{M})$, and 2,5 , and $10 \mu \mathrm{M}$ concentrations of ATO for $72 \mathrm{hr}$ and cytotoxicity was measured. As shown in Figure 3(a), Indo has no cytotoxic effect at 1, 10, and $50 \mu \mathrm{M}$. However, combinations of noneffective doses of ATO $(2,5 \mu \mathrm{M})$ and Indo $(1,10 \mu \mathrm{M})$ have significantly decreased the viability of A549 cells. When cells are treated with the combination of ATO $2 \mu \mathrm{M}$ and Indo $10 \mu \mathrm{M}$, the viability is reduced by $30 \%$ (Figure $3(\mathrm{~d})$ ). Indo $10 \mu \mathrm{M}$ has significantly augmented the antiproliferative effect of ATO 5 and $10 \mu \mathrm{M}$ to $60 \%$ and $80 \%$, respectively $\left({ }^{* * *} P<0.001\right.$ and ${ }^{*} P<0.05$, compared to ATO alone). These results suggest that noneffective dose of Indo $(10 \mu \mathrm{M})$ has increased the cytotoxicity of low doses of ATO synergistically. Compared to ATO alone, combination of Indo $50 \mu \mathrm{M}$ with all the concentrations of ATO significantly decreased the cell proliferation $\left({ }^{* * *} P<\right.$ 0.001 ) and Indo $50 \mu \mathrm{M}$ induced maximum effect on ATO toxicity. Interestingly a combination of Indo $50 \mu \mathrm{M}$ and ATO 5 or $10 \mu \mathrm{M}$ generates similar growth inhibition to Indo $800 \mu \mathrm{M}$ alone and 50-100 percent higher than ATO alone. Figure 3(b) shows the effect of combination of ATO and Cel on A549 proliferation. Cel has reduced cell proliferation by $20 \%$ at $75 \mu \mathrm{M}$ (Figure 3(b)); however, this effect is not significant compared to control. When various doses of Cel are combined with ATO, the cytotoxicity is similar to ATO 


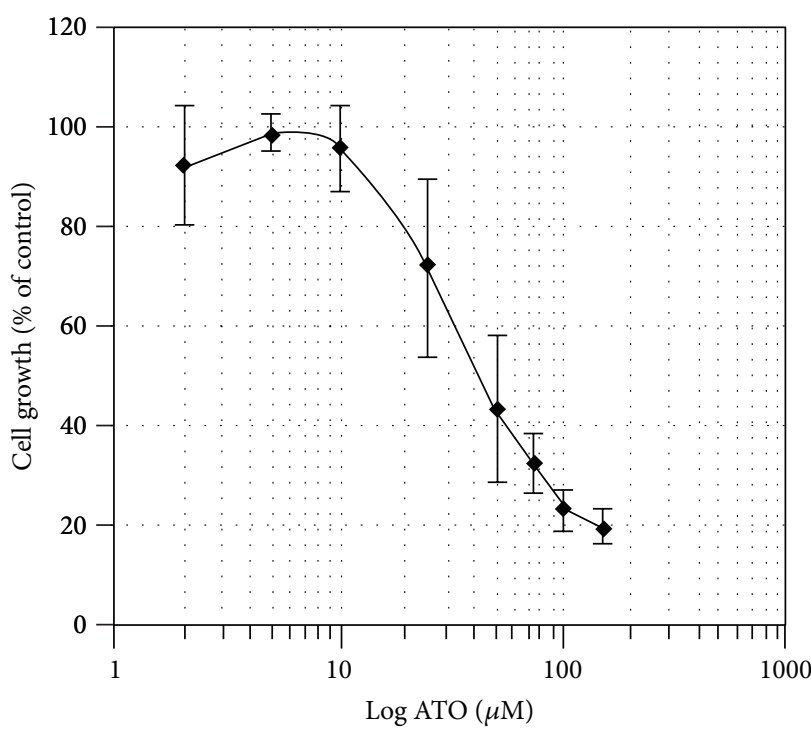

(a)

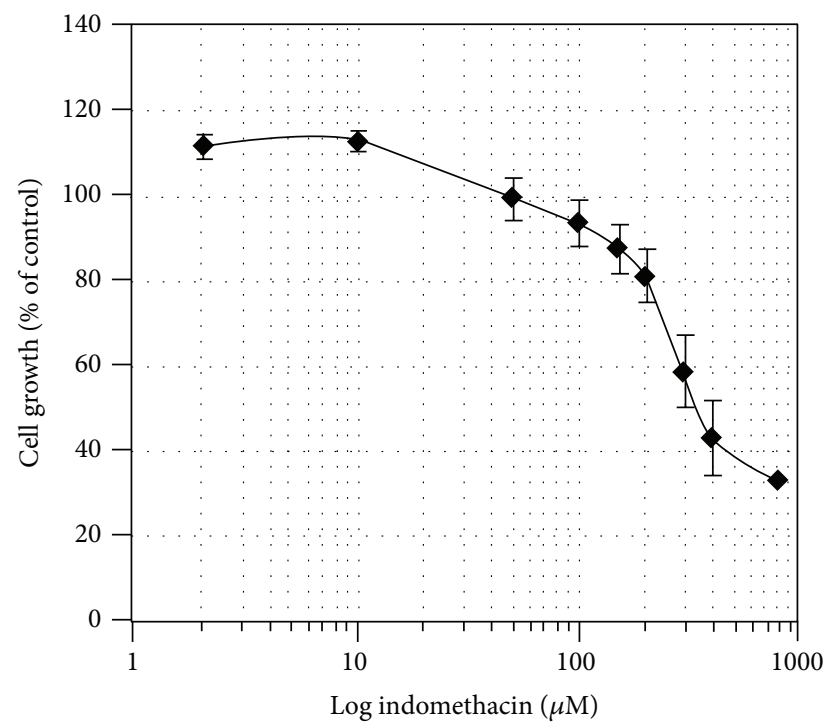

(c)

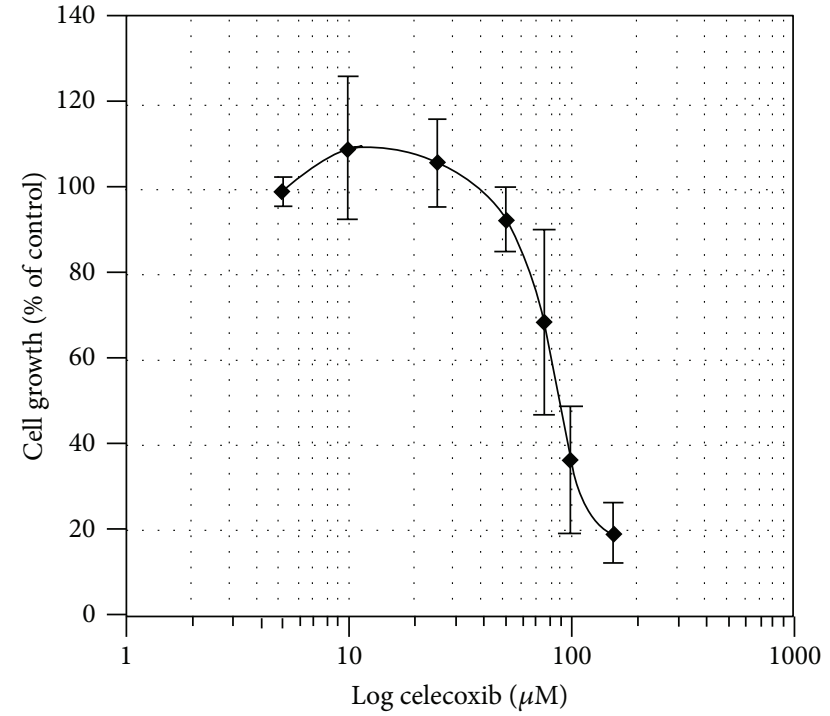

(b)

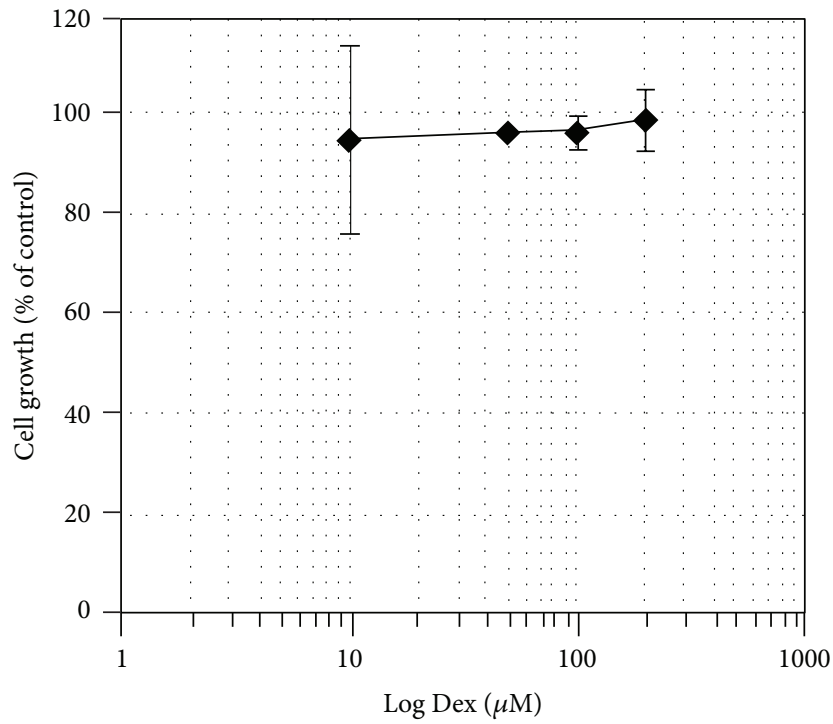

(d)

Figure 2: Effect of different concentrations of ATO (a), Cel (b), Indo (c), and Dex (d) on the growth of A549 cell line (Mean \pm SE, $n=4)$.

alone. Although the proliferation is reduced in the combination of ATO and Cel, the changes are not significantly different from ATO alone. ATO at low doses $(2,5 \mu \mathrm{M})$ has increased celecoxib $75 \mu \mathrm{M}$ inhibitory effect and the ATOCel combination exhibits an additive effect (Figures 3(b)3(e)). Combination of Dex and ATO treatment did not alter the antiproliferative effect of ATO in A549 cells (Figures $3(\mathrm{c})-3(\mathrm{f}))$. Even in low doses of ATO, cotreatment with Dex slightly increased the proliferation of cells.

3.3. ATO Decreases the Expression of COX-2 mRNA DoseDependently. Considering the role of COX-2 and COX inhibition in lung cancer [26], we have assessed the mRNA expression of COX-2 with different concentrations of ATO as well as ATO $2 \mu \mathrm{M}$ combination with Indo. Figure 4(a) shows that ATO has decreased the COX-2 expression in a dosedependent manner (Figures 4(a) and 4(b)) and at ATO $10 \mu \mathrm{M}$ there is $50 \%$ reduction in COX-2 expression. Treatment of A549 cells with Indo has increased the COX-2 expression dose-dependently (Figure 4(c)). The Indo-induced COX-2 expression has been inhibited by addition of ATO $2 \mu \mathrm{M}$ to the cells (Figure 4(c)).

3.4. Expression of Cox-2, Akt, ERK1/2, p38, JNK, and Bax Proteins in the Cells Treated with ATO, Indo, Dex, ATO/Indo, and ATO/Dex Combinations. To address the role of proteins involved in the apoptosis and survival, the expression of Akt, ERK1/2, p38, JNK, and Bax proteins was determined by western blotting analysis. The expression of COX-2 protein decreased dose-dependently by ATO especially in the dose of 


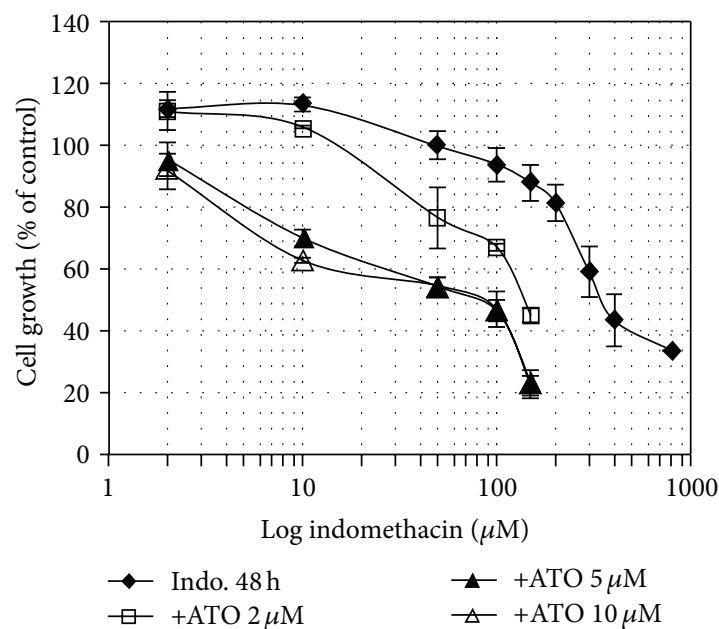

(a)

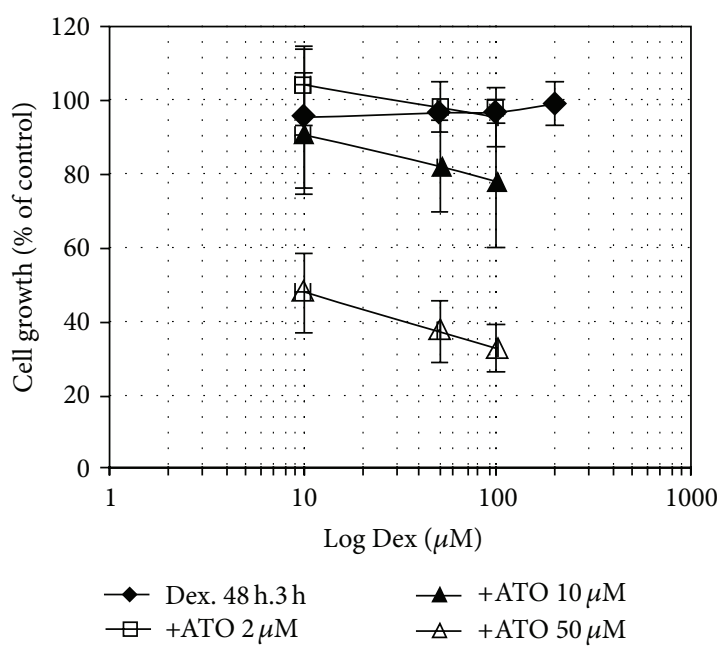

(c)

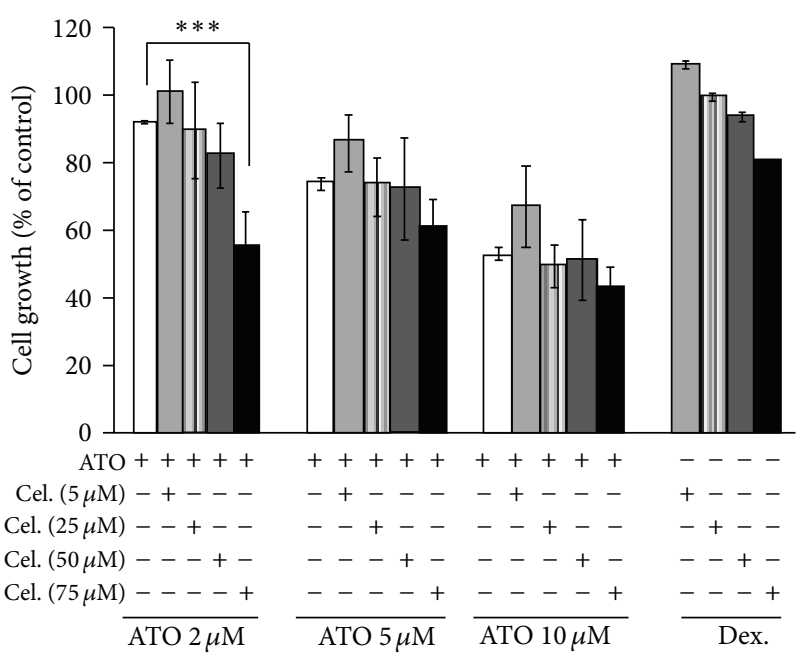

(e)

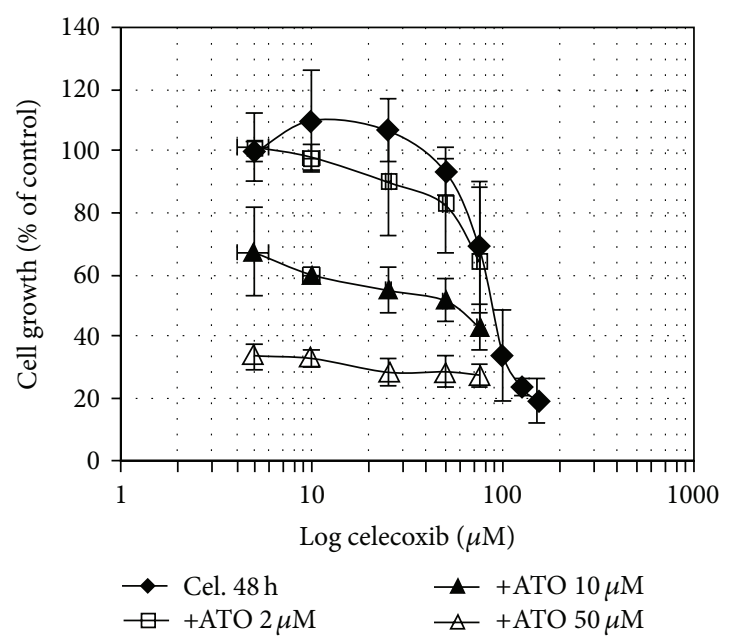

(b)

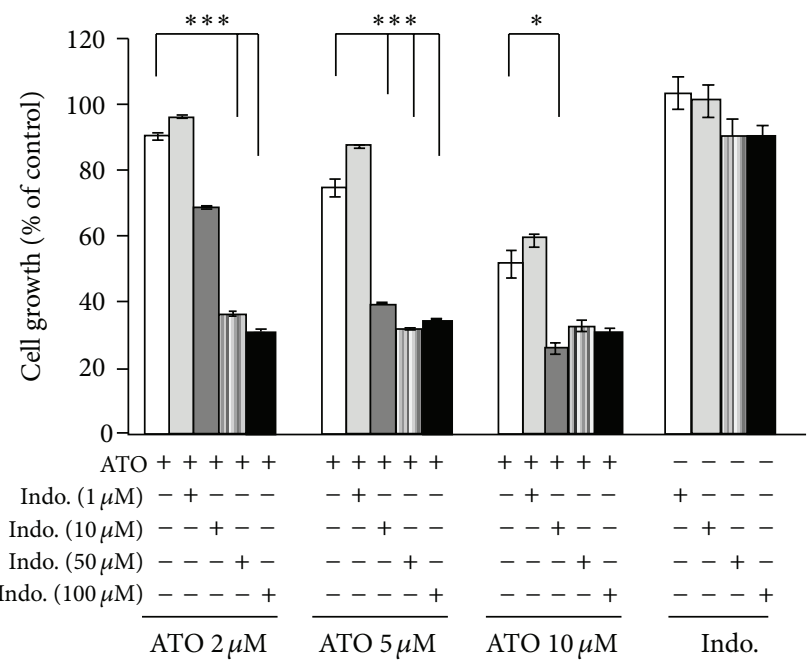

(d)

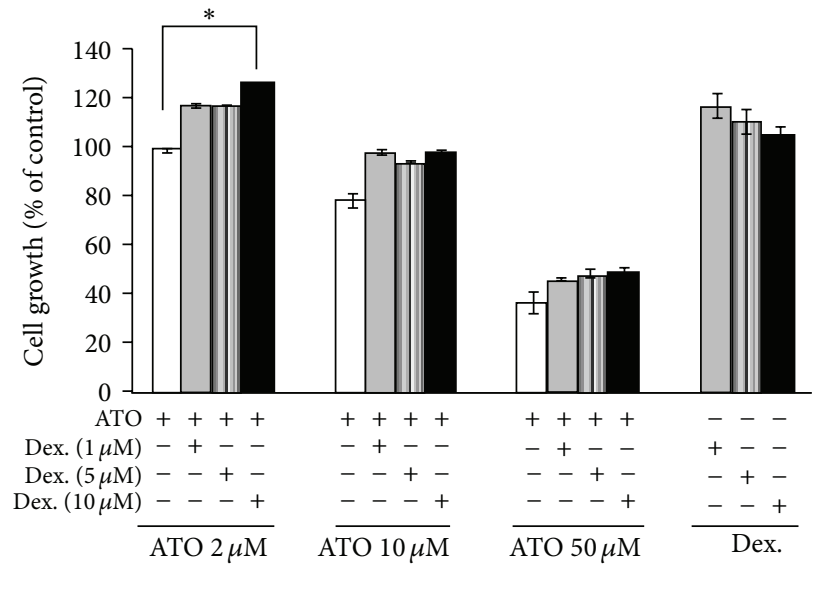

(f)

Figure 3: Inhibitory effects of single (a-c) and combination (d-f) of ATO and Indo, Cel and Dex on A549 lung cancer cell proliferation (Mean \pm SE, $n=4 ;{ }^{*} P<0.05,{ }^{* *} P<0.01$ and ${ }^{* * *} P<0.001$ ). 


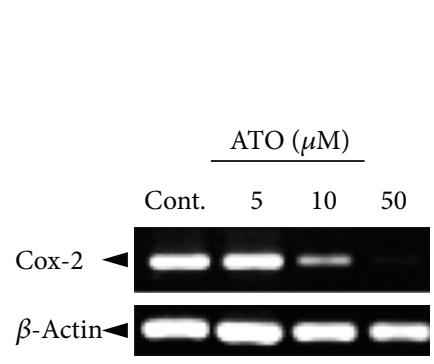

(a)

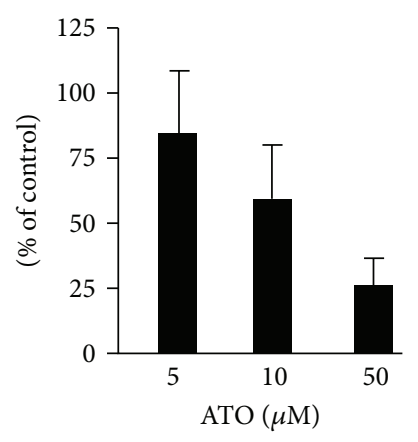

(b)

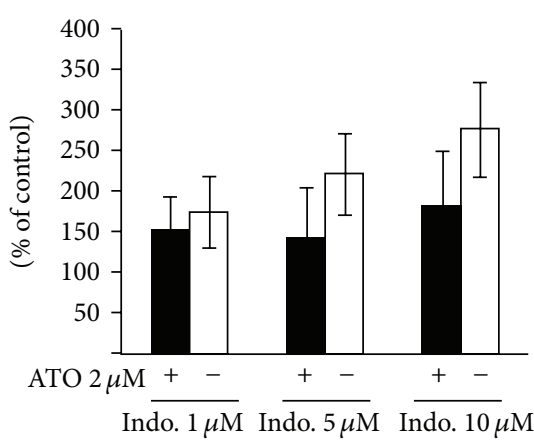

(c)

FIGURE 4: The effects of ATO and Indo and their combinations on the expression of COX-2 mRNA. (a) RT-PCR reaction products were resolved on $1 \%$ agarose gel and stained with Ethidium bromide. (b) Densitometric analyses of COX-2 mRNA expression is presented as the band's density to control ( $\beta$-actin) of three independent experiments (Mean \pm SE, $n=3$ ). (c) The effect of Indo alone (light columns) and combination with ATO $2 \mu \mathrm{M}$ (dark columns) on COX-2 expression.
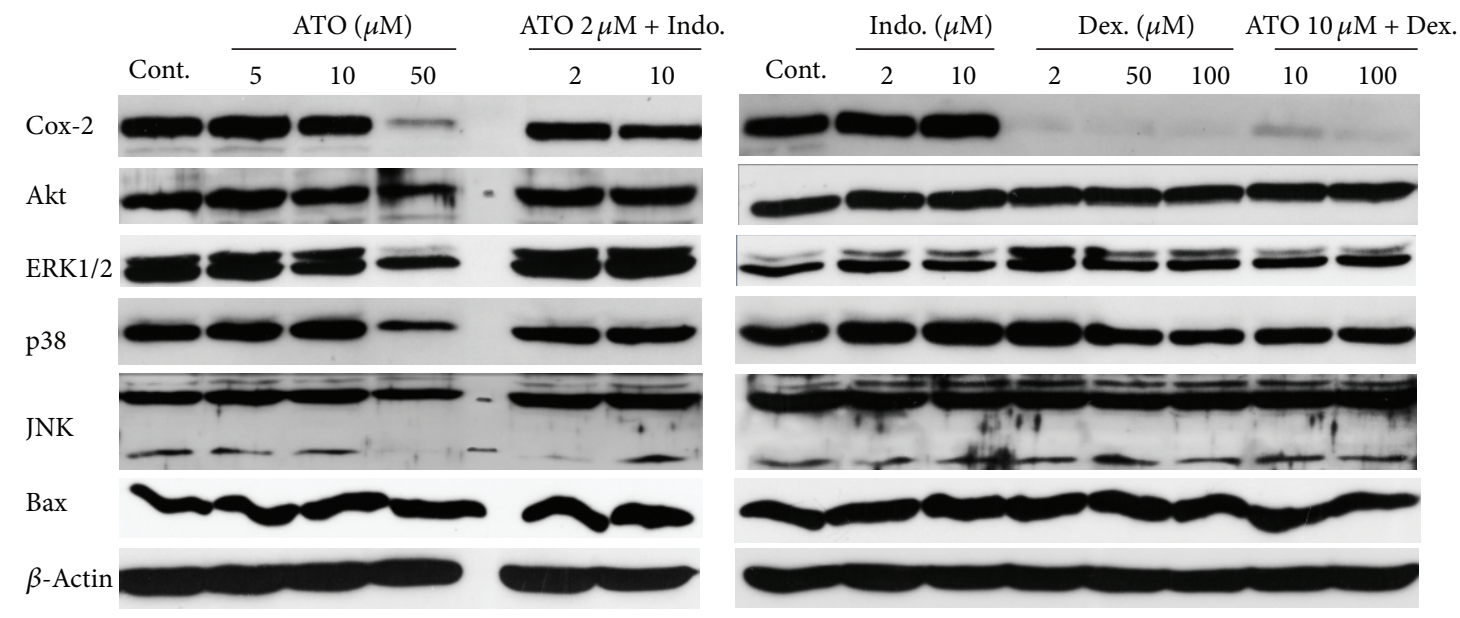

Figure 5: Western blot analysis of COX-2, Akt, ERK1/2, p38, JNK, and Bax proteins in A549 cells treated with ATO, Indo, Dex, ATO + Indo, and ATO + Dex combinations.

$50 \mu \mathrm{M}$ (Figure 5). Indo alone did not change the expression of COX-2 protein. However, combination of ATO $2 \mu \mathrm{M}$ and Indo $(2$ and $10 \mu \mathrm{M})$ decreased the COX-2 protein expression. ERK1/2 and $\mathrm{p} 38$ proteins levels were decreased with $50 \mu \mathrm{M}$ ATO treatment but remained unchanged with other treatments. Akt, Bax, and JNK seemed to be unchanged with different treatments.

Dex alone and in combination with ATO decreased expression of COX-2 protein completely. Furthermore, Dex decreased p38 and ERK1/2 proteins expressions dosedependently which remained unaltered in combination with ATO.

3.5. ERK and p38 Proteins Were Highly Phosphorylated in the Cells Treated with ATO/Indo Combination. Since the change in the total ERK and $\mathrm{p} 38$ protein expressions was remarkable, we investigated the phosphorylation of ERK and p38 proteins in the ATO, Indo and ATO/Indo treatments. As shown in Figure 6, treatment of A549 cells with ATO and Indo alone lowered the phospho-ERK at $24 \mathrm{hrs}$; however,

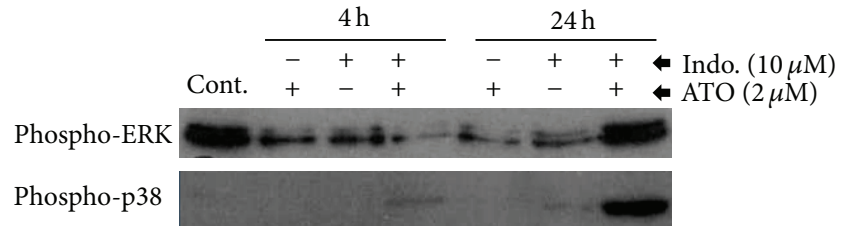

FIGURE 6: Phosphorylation of p38 and ERK in A549 cells treated with ATO, Indo, and ATO/Indo combination.

in cells treated with both ATO/Indo, the phosphorylation of ERK was increased and reached maximum level at $24 \mathrm{hr}$. Phosphorylation of p38 did not change in ATO and Indo single treatments. However, combination of ATO/Indo induced phosphorylation of p38 at $4 \mathrm{hrs}$ and increased phospho-p38 to a remarkable level at $24 \mathrm{hr}$, suggesting a synergistic effect of combination treatment on $\mathrm{p} 38$ pathway activation.

3.6. Both ATO and Indo Activate Caspase-3. To address the role of caspase- 3 in the cytotoxicity of ATO, Indo, and 


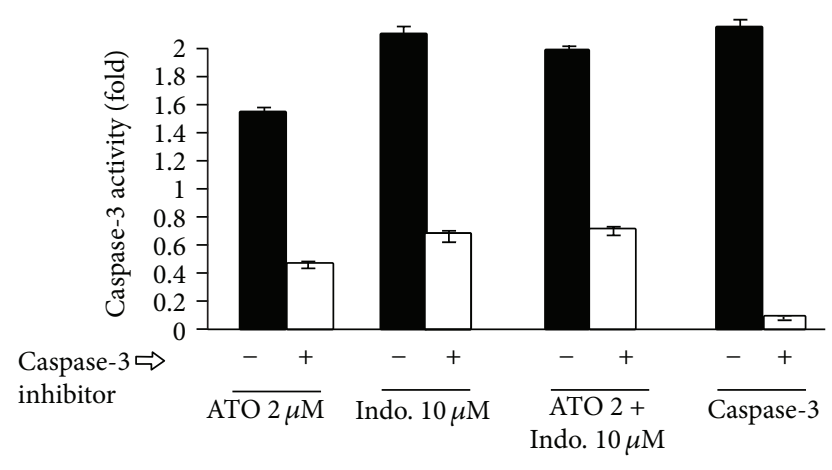

FIGURE 7: Activation of caspase-3 in A549 cells treated with ATO, Indo, and $\mathrm{ATO} /$ Indo combination.

ATO/Indo combination, the caspase- 3 activity was measured. As shown in Figure 7, caspase-3 activity increased 1.2 and 1.6 fold with ATO $2 \mu \mathrm{M}$ and Indo $10 \mu \mathrm{M}$, respectively. Increase in the caspase- 3 activity in the cells treated with combination of ATO $2 \mu \mathrm{M}$ and Indo $10 \mu \mathrm{M}$ was similar to that of Indo $10 \mu \mathrm{M}$. Caspase-3 inhibitor-treated cell lysate control showed that perhaps some other caspases are being activated in the treated cells.

\section{Discussion}

Combination therapy with agents that hire different signaling pathways is a promising strategy for overcoming drug resistance in cancerous cells and for increasing treatment efficacy and/or decreasing drug toxicity [27]. The present findings indicate that Indo increases the cytotoxicity of ATO in human lung cancer cell line A549. This event is associated with activation of ERK and p38 MAPK signaling pathways.

Our study showed that ATO, Cel, and Indo dosedependently decreased cell viability $\left(\mathrm{IC}_{50} \mathrm{~s}\right.$ are $68.7,98.2$, and $396.5 \mu \mathrm{M}$, resp.). Considering this effect, Indo produces very weak effect $\left(\mathrm{IC}_{50}=396.5 \mu \mathrm{M}\right)$ compared to two other drugs. It has been shown that ATO mediates its cytotoxic effect by induction of apoptosis via disruption of mitochondrial transmembrane potentials and caspase- 3 activation in various cell lines and human lymphocytes [18, 28]. Therefore, the cytotoxic effect of arsenic is related to apoptotic pathways since caspase- 3 has been activated (Figure 7). On the other hand, accumulating body of evidence suggests that COX enzymes, especially COX-2, have been increased in many cancers including lung cancers $[4,6]$. Thus, the inhibition of COX enzymes and in particular COX-2 can be accounted for the cytotoxic effect of $\mathrm{Cel}$ and Indo treatments. However, our results indicate a dramatic cytotoxicity with combinations of nontoxic doses of Cel or Indo with ATO in A549 cells (Figure 3). These results are of importance since very low doses of ATO and Indo (or Cel) have exerted significant cytotoxicity. The ATO/Indo combination treatment produced synergistic effect in all doses of ATO/Indo. Several combinations of NSAIDs with other chemopreventive drugs have previously been investigated in the lung cancers [22-24, 29, 30]. Lines of evidence show that anticancer effects of NSAIDs are not totally dependent on selectivity of COX-2 inhibition
$[9,10,31]$. This perhaps justifies the difference in the observed effects of Indo/ATO and Cel/ATO combinations. In this regard, we have tested change in COX-2 expression (at mRNA and protein level) as well as several apoptosis-related proteins from MAPKs pathways as potential mechanisms for the observed enhanced cytotoxicity of indo/ATO combination. ATO dose-dependently has decreased COX-2 mRNA expression (Figure 4(a)); however at low dose $(2 \mu \mathrm{M})$, ATO has opposed the increase in COX-2 expression induced by Indo (Figure 4(c)). This is in consistent with the Han et al. [32] report that shows ATO decrease expression of COX-2. Besides, Dex has strong inhibitory effect on COX-2 expression (Figure 5) and little cytotoxic effect in these cells. When we evaluated the caspase- 3 activation, ATO $(2 \mu \mathrm{M})$ and Indo $(10 \mu \mathrm{M})$ (as single or combination) have increased caspase- 3 activation and therefore induced apoptosis.

Changes in expression of the proteins of MAPK pathways have not been prominent except decreasing in p38, ERK1/2, and Akt proteins with ATO $50 \mu \mathrm{M}$. However, activation of phospho-ERK and phospho-p38 is noticeable when combination of ATO $2 \mu \mathrm{M}$ and Indo $10 \mu \mathrm{M}$ has been used. These findings are in agreement with other studies that have reported activation of MAPK pathways with ATO and Indo alone $[19,21,33]$. MAPKs including ERK1/2, p38, and JNK have many important regulatory roles in the proliferation and apoptosis of the cells [34]. In general, JNK and p38 pathways are activated by stress stimuli and are involved in apoptosis, while ERK1/2 pathway is preferentially activated in response to growth factors [35]. Whereas ERK activation has generally been associated with antiapoptotic effects, activation of ERK has also been shown to be necessary for the cytotoxicinduced apoptosis [36]. We have previously shown that ATO treatment increases $\mathrm{p} 38$ and ERK expression in promyelocyte of APL patients [21]. Thus changes in MAPK pathways could be accounted for the ATO effect.

To our knowledge based on a search of literature no study has been conducted to assess the combination of Indo and ATO on the cancerous cells. Instead, in several studies the antiproliferative and apoptotic effects of sulindac, a structural isoform of indomethacin, have been studied. In a study on the NCI-H157 human lung cancer cells, Park et al. [37] showed that combination of ATO $(2.5 \mu \mathrm{M})$ and sulindac $(5 \mu \mathrm{M})$ increased apoptosis, reactive oxygen species (ROS), and oxidative stress, as evidenced by the heme oxygenase1 (HO-1) expression and phosphorylation of ERK. Jin et al. [22] studied combination effect of ATO $(1 \mu \mathrm{M})$ and sulindac $(200 \mu \mathrm{M})$ on the H1299 human nonsmall cell lung carcinoma cells. They noted collapse of mitochondrial membrane potential and activation of caspase- 3 in the cells cotreated with sulindac/ATO. Furthermore, the authors reported activation of JNK downstream of ROS generation. We here report phosphorylation of ERK in ATO/Indo treated cells and a strong activation of p38 kinase which can be involved in mediated stress induced cell death. However, ATO/Indo activated phosphorylation of p38 is in contrast with Jin et al. findings [22]. This may be due to cell type and/or involvement of this pathway in cytotoxicity.

The effect of low dose ATO/indo combination on cytotoxicity of A549 can be a multiple pathway function. It has been 
shown that indomethacin induces apoptosis in vivo [38] and in vitro in some cancerous cells including lung $[7,8]$, colon $[39,40]$, and leukemia [41]. In this report, production of ROS has been mentioned as the main mechanism of apoptotic effect $[42,43]$. Besides, ROS also plays an important role in the ATO-induced apoptosis and cell death [28]. Consistent with this hypothesis, accumulating evidence indicates that Lbuthionine-sulfoximine (BSO), a drug that depletes intracellular glutathione (GSH) and generates ROS, can sensitize the lung cancerous cells to ATO-induced cell death [24, 42, 4446]. Moreover, ROS can activate ERK1/2 pathway [47] as well as p38 kinase $[47,48]$. Thus, increase in p38 kinase and ERK activation besides change in COX-2 expression can be accounted for the ATO/indo induction of apoptosis in low doses.

\section{Conclusion}

In conclusion we here report a combination of low doses of ATO and indomethacin as strong inducer of apoptosis in A549. This finding is important since the doses of ATO and indomethacin are practically noneffective when used as single treatment. Thus, low dose combination may provide better treatment with less adverse effect in patient which needs to be studied in future.

\section{Acknowledgment}

This work was supported by a Grant from the Chancellor of Research, Tehran University of Medical Sciences (no. 87-0433-8063).

\section{References}

[1] R. Stupp, C. Monnerat, A. T. Turrisi III, M. C. Perry, and S. Leyvraz, "Small cell lung cancer: state of the art and future perspectives," Lung Cancer, vol. 45, no. 1, pp. 105-117, 2004.

[2] G. K. Schwartz, Combination Cancer Therapy: Modulators and Potentiators, Humana Press, Totowa, NJ, USA, 2005.

[3] M. H. Cohen, S. Hirschfeld, S. F. Honig et al., "Drug approval summaries: arsenic trioxide, tamoxifen citrate, anastrazole, paclitaxel, bexarotene," Oncologist, vol. 6, no. 1, pp. 4-11, 2001.

[4] T. Hida, Y. Yatabe, H. Achiwa et al., "Increased expression of cyclooxygenase 2 occurs frequently in human lung cancers, specifically in adenocarcinomas," Cancer Research, vol. 58, no. 17, pp. 3761-3764, 1998.

[5] O. N. Tucker, A. J. Dannenberg, E. K. Yang et al., "Cyclooxygenase-2 expression is up-regulated in human pancreatic cancer," Cancer Research, vol. 59, no. 5, pp. 987-990, 1999.

[6] Y. Hosomi, T. Yokose, Y. Hirose et al., "Increased cyclooxygenase 2 (COX-2) expression occurs frequently in precursor lesions of human adenocarcinoma of the lung," Lung Cancer, vol. 30, no. 2, pp. 73-81, 2000.

[7] D. J. A. de Groot, T. Timmer, D. C. J. Spierings, T. K. P. Le, S. de Jong, and E. G. E. de Vries, "Indomethacin-induced activation of the death receptor-mediated apoptosis pathway circumvents acquired doxorubicin resistance in SCLC cells," British Journal of Cancer, vol. 92, no. 8, pp. 1459-1466, 2005.

[8] D. J. A. de Groot, M. Van Der Deen, T. K. P. Le, A. Regeling, S. de Jong, and E. G. E. de Vries, "Indomethacin induces apoptosis via a MRP1-dependent mechanism in doxorubicin-resistant smallcell lung cancer cells overexpressing MRP1," British Journal of Cancer, vol. 97, no. 8, pp. 1077-1083, 2007.

[9] S. Grösch, I. Tegeder, E. Niederberger, L. Bräutigam, and G. Geisslinger, "COX-2 independent induction of cell cycle arrest and apoptosis in colon cancer cells by the selective COX-2 inhibitor celecoxib," The FASEB Journal, vol. 15, no. 14, pp. 27422744, 2001.

[10] J. A. Sánchez-Alcázar, D. A. Bradbury, L. Pang, and A. J. Knox, "Cyclooxygenase (COX) inhibitors induce apoptosis in nonsmall cell lung cancer through cyclooxygenase independent pathways," Lung Cancer, vol. 40, no. 1, pp. 33-44, 2003.

[11] M. Lasa, M. Brook, J. Saklatvala, and A. R. Clark, "Dexamethasone destabilizes cyclooxygenase 2 mRNA by inhibiting mitogen-activated protein kinase p38," Molecular and Cellular Biology, vol. 21, no. 3, pp. 771-780, 2001.

[12] R. Newton, J. Seybold, L. M. E. Kuitert, M. Bergmann, and P. J. Barnes, "Repression of cyclooxygenase- 2 and prostaglandin E2 release by dexamethasone occurs by transcriptional and posttranscriptional mechanisms involving loss of polyadenylated mRNA," Journal of Biological Chemistry, vol. 273, no. 48, pp. 32312-32321, 1998.

[13] I. Henzi, B. Walder, and M. R. Tramèr, "Dexamethasone for the prevention of postoperative nausea and vomiting: a quantitative systematic review," Anesthesia and Analgesia, vol. 90, no. 1, pp. 186-194, 2000.

[14] S. Jagannath, B. G. M. Durie, J. Wolf et al., "Bortezomib therapy alone and in combination with dexamethasone for previously untreated symptomatic multiple myeloma," British Journal of Haematology, vol. 129, no. 6, pp. 776-783, 2005.

[15] P. G. Richardson, P. Sonneveld, M. W. Schuster et al., "Bortezomib or high-dose dexamethasone for relapsed multiple myeloma," New England Journal of Medicine, vol. 352, no. 24, pp. 2487-2498, 2005.

[16] T. Hida, K. I. Kozaki, H. Muramatsu et al., "Cyclooxygenase2 inhibitor induces apoptosis and enhances cytotoxicity of various anticancer agents in non-small cell lung cancer cell lines," Clinical Cancer Research, vol. 6, no. 5, pp. 2006-2011, 2000.

[17] S. Y. Sun, C. P. Schroeder, P. Yue, D. Lotan, W. K. Hong, and R. Lotan, "Enhanced growth inhibition and apoptosis induction in NSCLC cell lines by combination of celecoxib and 4HPR at clinically relevant concentrations," Cancer Biology and Therapy, vol. 4, no. 4, pp. 407-413, 2005.

[18] X. Cai, Y. L. Shen, Q. Zhu et al., "Arsenic trioxide-induced apoptosis and differentiation are associated respectively with mitochondrial transmembrane potential collapse and retinoic acid signaling pathways in acute promyelocytic leukemia," Leukemia, vol. 14, no. 2, pp. 262-270, 2000.

[19] A. M. Bode and Z. Dong, "The paradox of arsenic: molecular mechanisms of cell transformation and chemotherapeutic effects," Critical Reviews in Oncology/Hematology, vol. 42, no. 1, pp. 5-24, 2002.

[20] A. Mandegary and M. Mehrabani, "Effects of arsenic trioxide, all-trans-retinoic acid and dexamethasone on NB4 cell line," DARU, Journal of Pharmaceutical Sciences, vol. 18, no. 4, pp. 303-309, 2010.

[21] A. Mandegary, R. Hosseini, S. H. Ghaffari et al., "The expression of p38, ERK1 and Bax proteins has increased during the treatment of newly diagnosed acute promyelocytic leukemia with arsenic trioxide," Annals of Oncology, vol. 21, no. 9, pp. 1884-1890, 2010. 
[22] H. O. Jin, S. K. Seo, S. H. Woo et al., "A combination of sulindac and arsenic trioxide synergistically induces apoptosis in human lung cancer H1299 cells via c-Jun NH2-terminal kinase-dependent Bcl-xL phosphorylation," Lung Cancer, vol. 61, no. 3, pp. 317-327, 2008.

[23] L. M. Lin, B. X. Li, J. B. Xiao, D. H. Lin, and B. F. Yang, "Synergistic effect of all-trans-retinoic acid and arsenic trioxide on growth inhibition and apoptosis in human hepatoma, breast cancer, and lung cancer cells in vitro," World Journal of Gastroenterology, vol. 11, no. 36, pp. 5633-5637, 2005.

[24] Y. H. Han, S. Z. Kim, S. H. Kim, and W. H. Park, "Induction of apoptosis in arsenic trioxide-treated lung cancer A549 cells by buthionine sulfoximine," Molecules and Cells, vol. 26, no. 2, pp. 158-164, 2008.

[25] L. Navidpour, H. Shafaroodi, K. Abdi et al., "Design, synthesis, and biological evaluation of substituted 3-alkylthio-4,5-diaryl4H-1,2,4-triazoles as selective COX-2 inhibitors," Bioorganic and Medicinal Chemistry, vol. 14, no. 8, pp. 2507-2517, 2006.

[26] J. R. Brown and R. N. DuBois, "Cyclooxygenase as a target in lung cancer," Clinical Cancer Research, vol. 10, no. 12, part 12, pp. 4266s-4269s, 2004.

[27] F. R. Hirsch and S. M. Lippman, "Advances in the biology of lung cancer chemoprevention," Journal of Clinical Oncology, vol. 23, no. 14, pp. 3186-3197, 2005.

[28] L. K. Nutt, V. Gogvadze, W. Uthaisang, B. Mirnikjoo, D. J. McConkey, and S. Orrenius, "Indirect effects of Bax and Bak initiate the mitochondrial alterations that lead to cytochrome c release during arsenic trioxide-induced apoptosis," Cancer Biology and Therapy, vol. 4, no. 4, pp. 459-467, 2005.

[29] C. P. Schroeder, H. Kadara, D. Lotan et al., "Involvement of mitochondrial and Akt signaling pathways in augmented apoptosis induced by a combination of low doses of celecoxib and $\mathrm{N}$-(4-hydroxyphenyl) retinamide in premalignant human bronchial epithelial cells," Cancer Research, vol. 66, no. 19, pp. 9762-9770, 2006.

[30] A. F. Soriano, B. Helfrich, D. C. Chan, L. E. Heasley, P. A. Bunn Jr., and T. C. Chou, "Synergistic effects of new chemopreventive agents and conventional cytotoxic agents against human lung cancer cell lines," Cancer Research, vol. 59, no. 24, pp. 6178-6184, 1999.

[31] S. Grösch, T. J. Maier, S. Schiffmann, and G. Geisslinger, "Сyclooxygenase-2 (COX-2)-independent anticarcinogenic effects of selective COX-2 inhibitors," Journal of the National Cancer Institute, vol. 98, no. 11, pp. 736-747, 2006.

[32] S. S. Han, K. Kim, E. R. Hahm et al., "Arsenic trioxide represses constitutive activation of NF-kappaB and COX-2 expression in human acute myeloid leukemia, HL-60," Journal of Cellular Biochemistry, vol. 94, no. 4, pp. 695-707, 2005.

[33] A. Verma, M. Mohindru, D. K. Deb et al., "Activation of Racl and the p38 mitogen-activated protein kinase pathway in response to arsenic trioxide," Journal of Biological Chemistry, vol. 277, no. 47, pp. 44988-44995, 2002.

[34] A. S. Dhillon, S. Hagan, O. Rath, and W. Kolch, "MAP kinase signalling pathways in cancer," Oncogene, vol. 26, no. 22, pp. 3279-3290, 2007.

[35] Z. Xia, M. Dickens, J. Raingeaud, R. J. Davis, and M. E. Greenberg, "Opposing effects of ERK and JNK-p38 MAP kinases on apoptosis," Science, vol. 270, no. 5240, pp. 1326-1331, 1995.

[36] X. Wang, J. L. Martindale, and N. J. Holbrook, "Requirement for ERK activation in cisplatin-induced apoptosis," Journal of Biological Chemistry, vol. 275, no. 50, pp. 39435-39443, 2000.
[37] J. H. Park, E. J. Kim, H. Y. Jang et al., "Combination treatment with arsenic trioxide and sulindac enhances apoptotic cell death in lung cancer cells via activation of oxidative stress and mitogen-activated protein kinases," Oncology Reports, vol. 20, no. 2, pp. 379-384, 2008.

[38] P. Maity, S. Bindu, S. Dey et al., "Indomethacin, a non-steroidal anti-inflammatory drug, develops gastropathy by inducing reactive oxygen species-mediated mitochondrial pathology and associated apoptosis in gastric mucosa: a novel role of mitochondrial aconitase oxidation," Journal of Biological Chemistry, vol. 284, no. 5, pp. 3058-3068, 2009.

[39] C. J. Loveridge, A. D. H. MacDonald, H. C. Thoms, M. G. Dunlop, and L. A. Stark, "The proapoptotic effects of sulindac, sulindac sulfone and indomethacin are mediated by nucleolar translocation of the RelA(p65) subunit of NF- $\kappa \mathrm{B}$," Oncogene, vol. 27, no. 18, pp. 2648-2655, 2008.

[40] Y. J. Zhang, Y. J. Bao, Q. Dai et al., "MTOR signaling is involved in indomethacin and nimesulide suppression of colorectal cancer cell growth via a COX-2 independent pathway," Annals of Surgical Oncology, vol. 18, no. 2, pp. 580-588, 2011.

[41] G. S. Zhang, C. Q. Tu, G. Y. Zhang, G. B. Zhou, and W. L. Zheng, "Indomethacin induces apoptosis and inhibits proliferation in chronic myeloid leukemia cells," Leukemia Research, vol. 24, no. 5, pp. 385-392, 2000.

[42] E. E. Caicedo-Granados, B. R. Wuertz, P. H. Marker, G. S. Lee, and F. G. Ondrey, "The effect of indomethacin on paclitaxel sensitivity and apoptosis in oral squamous carcinoma cells: the role of nuclear factor- $\kappa \mathrm{b}$ inhibition," Archives of OtolaryngologyHead and Neck Surgery, vol. 137, no. 8, pp. 799-805, 2011.

[43] M. P. Draper, R. L. Martell, and S. B. Levy, "Indomethacinmediated reversal of multidrug resistance and drug efflux in human and murine cell lines overexpressing MRP, but not Pglycoprotein," British Journal of Cancer, vol. 75, no. 6, pp. 810815, 1997.

[44] L. M. Lin, B. X. Li, J. B. Xiao, D. H. Lin, and B. F. Yang, "Synergistic effect of all-trans-retinoic acid and arsenic trioxide on growth inhibition and apoptosis in human hepatoma, breast cancer, and lung cancer cells in vitro," World Journal of Gastroenterology, vol. 11, no. 36, pp. 5633-5637, 2005.

[45] J. Dai, R. S. Weinberg, S. Waxman, and Y. Jing, "Malignant cells can be sensitized to undergo growth inhibition and apoptosis by arsenic trioxide through modulation of the glutathione redox system," Blood, vol. 93, no. 1, pp. 268-277, 1999.

[46] H. Maeda, S. Hori, H. Ohizumi et al., "Effective treatment of advanced solid tumors by the combination of arsenic trioxide and L-buthionine-sulfoximine," Cell Death and Differentiation, vol. 11, no. 7, pp. 737-746, 2004.

[47] J. S. Pan, M. Z. Hong, and J. L. Ren, "Reactive oxygen species: a double-edged sword in oncogenesis," World Journal of Gastroenterology, vol. 15, no. 14, pp. 1702-1707, 2009.

[48] A. Matsuzawa and H. Ichijo, "Redox control of cell fate by MAP kinase: physiological roles of ASK1-MAP kinase pathway in stress signaling," Biochimica et Biophysica Acta, vol. 1780, no. 11, pp. 1325-1336, 2008. 


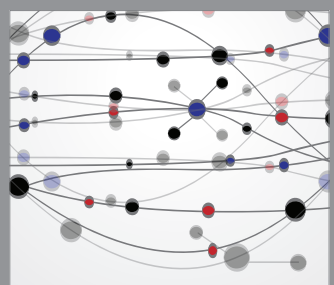

The Scientific World Journal
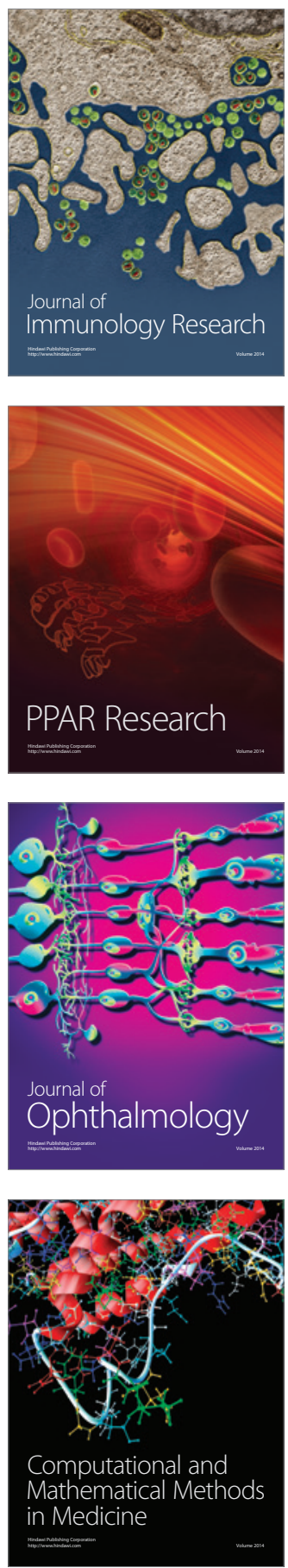

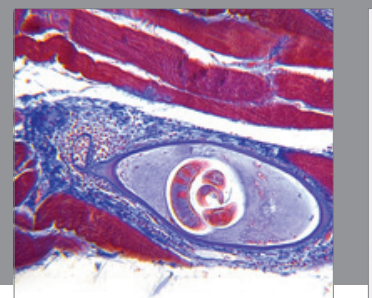

Gastroenterology

Research and Practice
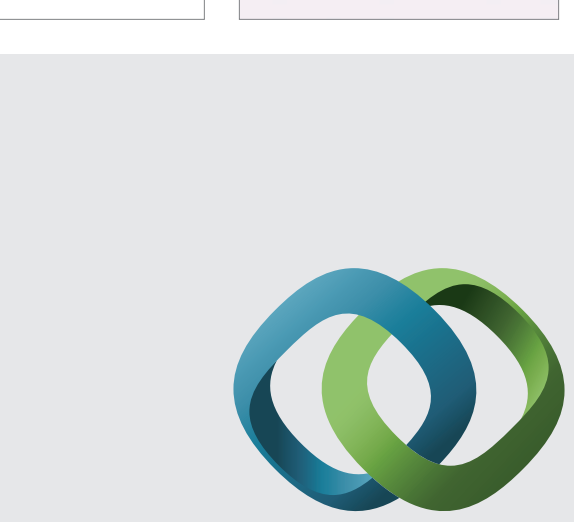

\section{Hindawi}

Submit your manuscripts at

http://www.hindawi.com
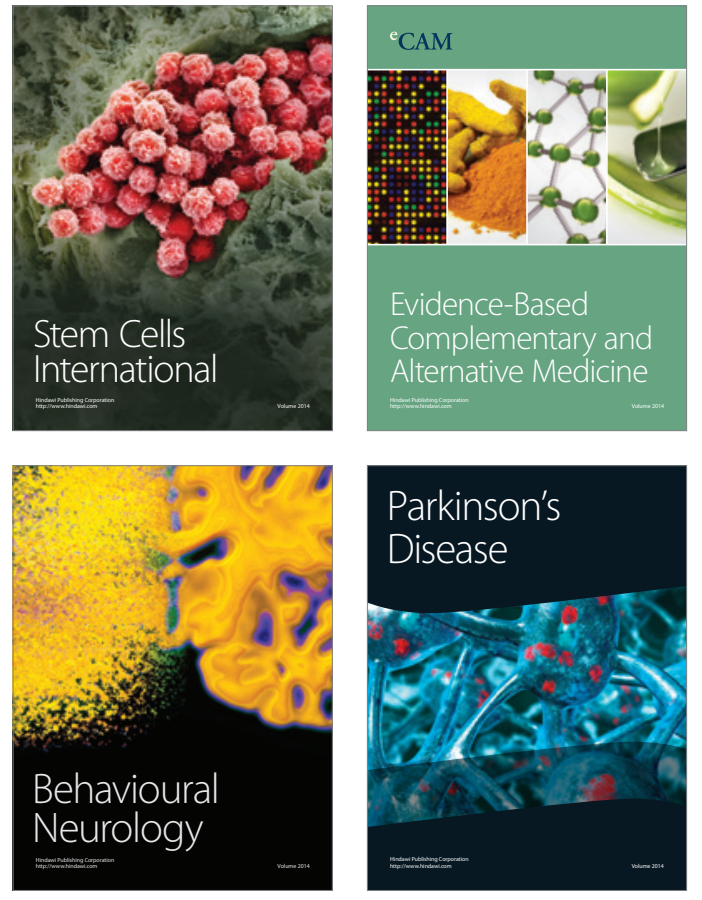
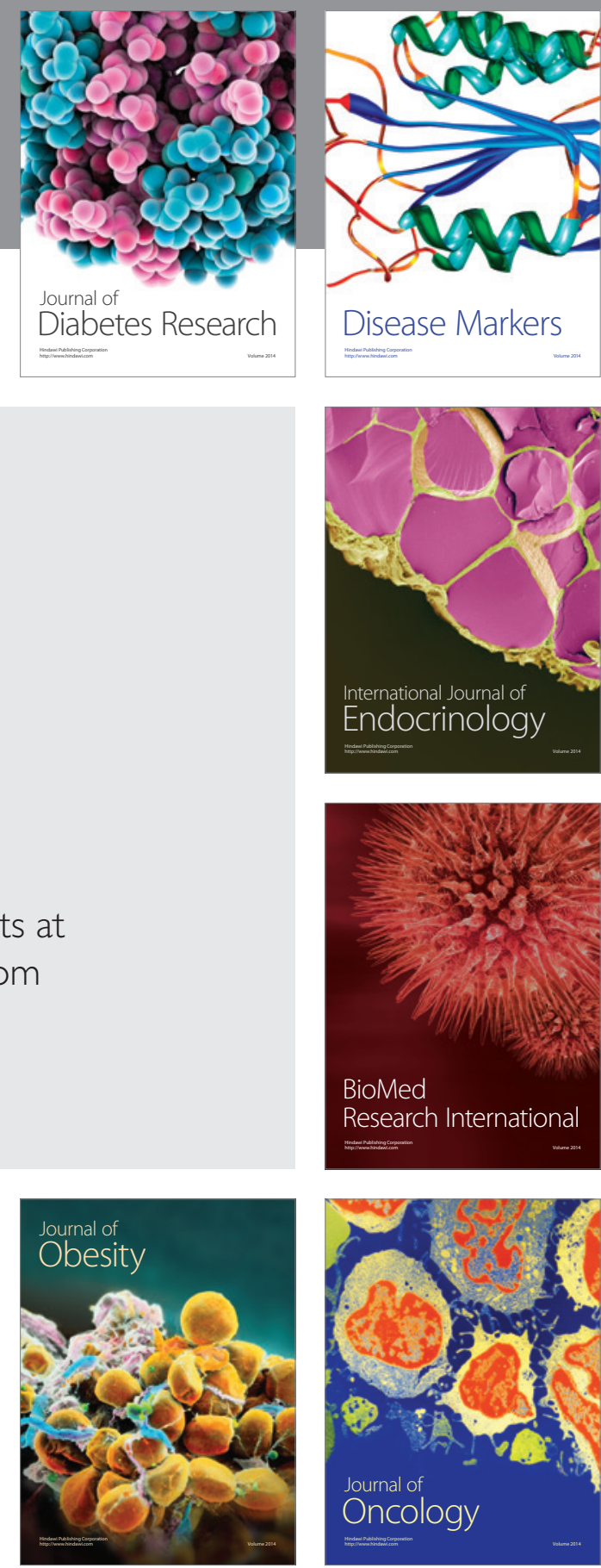

Disease Markers
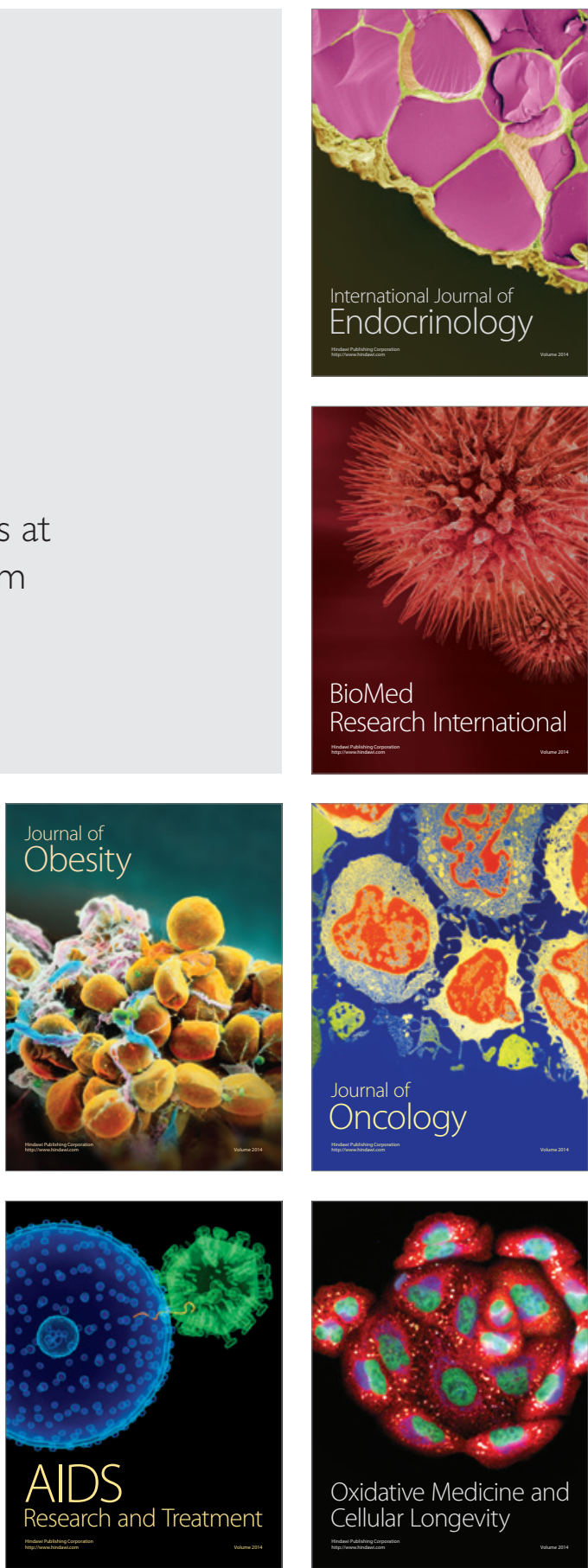